\title{
207 組合せ最適化問題における Proximate Optimality Principle を考慮したTabu Searchの探索効率改善 Improvement of Tabu Search considering a Proximate Optimality Principle in Combinatorial Optimization Problems
}

\author{
金澤 貴彦* 安田 恵一郎 (東京都立大学) \\ Takahiko Kanazawa, Keiichiro Yasuda (Tokyo Metropolitan University)
}

\begin{abstract}
Most of the actual problems with discrete mechanism can be formulated as a combinatorial optimization problem such as system scheduling problems. While many combinatorial optimization problems are supposed to be $\mathcal{N} \mathcal{P}$-Hard from the view point of complexity in a calculation theory. This means that it is extremely hard to obtain a strictly optimal solution within feasible computation time. Meta-heuristics is a new paradigm that aims to obtain an approximate solution within feasible computation time. In the meta-heuristics, Tabu search is one of the most effective algorithms for combinatorial optimization problems. While the intensification of Tabu Search is powerful, the diversification Tabu Search is not powerful. This paper proposes an algorithm - Tabu Search with multi-criteria for coordinating the intensification and diversification that takes a Proximate Optimality Principle (POP) into consideration - has several important features for solving combinatorial optimization problems. The Tabu Search with multi-criteria has two purpose, the value of objective functions and the evaluation of operations, these enable to achieve well-balanced search. The proposed algorithm is applied to Traveling Salesman Problems, that is typical combinatorial optimization problem, to verify the performance of search.
\end{abstract}

\section{1 はじめに}

近年, 複雑なシステムを最適に計画・運用するための手段と して, システム最適化の概念はますます重要な地位を築きつつ ある。そして, システムのスケジューリング問題など, 離散的 構造を持つ現実の多くの問題が組合せ最適化問題として定式 化できる。一般に, 組合せ最適化問題は以下のように定式化さ れる。

$$
\min f(x)
$$

$$
\text { subj. to } x \in \mathcal{F}(\mathcal{F}: \text { 実行可能領域 })
$$

しかしながら，その一方で数学における計算の複雑性の理論 により，その組合せ最適化問題の多くについて $\mathcal{N} \mathcal{P}$ 困難性が 示されている1。

このことは，大規模な現実の組合せ最適化問題の厳密な大 域的最適解を実用的な時間内に求めることが (計算機の処理能 力が今後も飛躍的に発展することを考慮に入れたとしても）一 般に絶望的であることを意味している。ところが，厳密な大域 的最適解を求める必要に迫られるケースは現赛的にはむしろ稀 で, ある程度精度の高い解が求まれば十分な場合が多いと考え られる。

メタヒューリスティクス (メ夕解法: 発見的近似解法) はこ のような背景のもとに提案された最適化における新しいパラダ イムで，厳密な証明はできないが人間の目から見て有効であろ うと考えられるヒューリスティクス (発見的操作)を含む近似解 法であるといえる。遺伝的アルゴリズム (Genetic Algorithm : GA)，模擬焼き鈍し法（Simulated Annealing：SA）, Tabu Search など,これまでメタ解法に属するアルゴリズムが数多 く提案されてきた。

一般に，問題を解くにあたっては対象とする問題の持つ特 徽をつかみ, それを最大限に活用する必要がある。組合せ最適 化問題においても，問題を解くにあたって有用であるうと考え られている POP (Proximate Optimality Principle) と呼ば れる特徵が存在する。POP とは「よい解同士は似通った構造 をもっている」という漠然とした仮定で, メ夕解法と組合せ最

\footnotetext{
${ }^{1}$ ある組合せ最適化問題が $\mathcal{N P}$ 困難であるということは，その問題 の蕨密な最適解を求めるために要する時間が, 最悪ケースにおいて対 象とする問題の規模の多項式オーダーで押さえることが不可能である ことを意味する。
}

適化問題との関連における重要な概念である。組合せ構造をも つ問題の中には POP が成立しない問題として偶奇性判定問題 (Parity Problem) や数分割問題などが挙げられるが [6], 組合 せ最適化問題に対するメ夕解法の多くは基本的に POP を考慮 した手法であると言える。

例えば遺伝的アルゴリズムでは対象とする問題の解を遺伝子 と捉え，淘汰によって遺伝子集団の中から環境に適合した良い 遺伝子を選択する。そして，淘汰によって得られた良い遺伝子 同士を交叉によって組合せ，さらによい遺伝子を生み出すこと を狙いとしている $[4]$ 。このように優れた遺伝子同士を組合せ て解を改善するという戦略が成功するためには，良い遺伝子同 士が（ランダムに生成した解同士には見られないような）何か しらの似通った構造を持っているという条件が必要となりここ れがまさにPOP の考虑に他ならない。

また，優れたメ夕解法の構築を考える上で鍵となる概念とし て集中化 (Intensification) と多様化 (Diversification) が挙げら れる [3]。集中化とは局所的な探索のメカニズムを意味し，短 期的な解の改善を目標とする概念であると考えられる。また， 多様化とは大域的探索のメカニズムを意味し，局所的な探索か らの脱出および長期的な解の改善を目標とする概念であると考 えられる。高い探索能力を実現するためには，集中化あるいは 多様化の一方に頼るのではなく，両者の特性をバランス良く兼 ね備えるようにアルゴリズムを構築することが有効である。

組合せ最適化問題に対するメ夕解法として高速かつ優れた探 索性能を持つといわれる Tabu Search[1, 2] は, Local Search に準ずる強力な集中化のメカニズムを持つアルゴリズムであ る。しかしながら多様化のメカニズムは Tabu Listによるもの のみであるため, 集中化・多様化のバランスの観点から, 大域 的探索については改良の余地があると考えられる。そこで本論 文では Tabu Search を基にして, POP を陽に考慮した多様化 のメカニズムを強化することによって探索能力を向上させるア ルゴリズムを提案する。

以下本論文の構成は次の通りである。まず次章で, アルゴ リズムを改良するにあたっての基本的戦略について概説する。 3 章ではメタヒューリスティクスおよび POP の概念について 考察し，代表的な組合せ最適化問題である巡回セールスマン問 題 (Traveling Salesman Problem : TSP) [5]において POP の成立を検証する。4 章では集中化と多様化および多軌道化に ついて検討し，具体的なアルゴリズムの改良の方法について述

日本機械学会〔NNo.02-03]第 5 回最適化シンポジウム講演論文集 (’02.10.12 13 京都) 
べる。 5 章では 4 章までの検討内容を基に，POP を陽に考慮し たアルゴリズムを提案する。6 章では POP が強く成立する典 型的な組合せ最適化問題として巡回セールスマン問題 (TSP) を取り上げ，提案手法の性能を検証する。 7 章はまとめで，本 論文の総括と今後の課題について述べる。

\section{2 アルゴリズム改良の基本的戦略}

既に述べたように，本論文では POP を考虑した多様化のメ カニズムを Tabu Search に加えることにより，探索効率を改 善することを狙いとしている。ここではその改良に関する基本 的な戦略について概説する。

従来の Tabu Search では解の評価基準として目的関数值の みを用いているが，本論文の提案手法では目的関数值の他に POPを陽に考慮した要素として，移動の際に用いるオペレー ションの良さを判断するための評価基準を導入する。これに よって効果的な探索において重要な要素である多様化を強化し， 探索性能を向上させることを狙いとしている。そのために組合 せ最適化問題の解を, 解を構成する何らかの部品の集合である と考え, メ夕解法における探索点の移動は解に含まれる部品の 組換えによって達成されると捉えることとする。

新たな評価基集の導入によって，提案手法では解の評価基準 が，集中化を考慮した目的関数值という基準・多様化を考虑し たオペレーションの評価という基淮の 2 つとなる。この 20 の評価基淮をバランスよく考慮するために多目的最適化におけ る Pareto 最適解の概念を導入し，集中化・多様化の 2 つを評 価基準とした Pareto 最適解集合を許容近傍内に構成する。そ して Pareto 最適解集合内のどの点に移動するかを探索状況に 応じて適応的に変化させることで集中化と多様化の耐立をさ せ，さらに探索軌道を多軌道化することによって対象となる問 題についての情報を効果的に収集し，探索の効率化を計ること とする。

次章以降ではこれらの戦略について詳しく説明する。

\section{3 メタヒューリスティクス}

メタヒューリスティクスは最適化における新しいパラダイム で，厳密な証明はできないが人間の目から見て有効であろうと 考えられるヒューリスティクス（発見的操作）を含む近似解法 であるといえる。

\subsection{Tabu Search のアルゴリズム $[1,2]$}

Tabu Search は近傍集合内の全ての解を評価し，その中で 評価値の優れている解に移動するという強力な Local Search のメカニズムを持つ。その一方で既に行った近傍生成操作を Tabu List に記憶し, Tabu List が記憶している間はその操作 を行うことを禁止することで探索点が元の解に戻ることを防ぎ， 広域探索を実現している。

Tabu Search のアルゴリズムを以下に示す。

【Tabu Search】

Step1：初期点を生成する。Tabu List $T$ を初期化する。

Step2: Tabu Listに含まれない移動可能な近傍 $N(x) / T$ 内で 目的関数値が最小の点に移動する。

Step3：Step2 での移動に用いた操作を Tabu List に追加する。

Step4: Step2〜Step3 までを規定の回数繰り返し，探索中に 求まった最良解を出力して終了。

しかしながら Tabu List のみに頼った多様化のメカニズム は強力な集中化のメカニズムと比較して十分な強力さを持って いるとは言えず，集中化と多様化のバランスが取れていない。 このため Tabu Search の多様化のメカニズムを強化するこ とにより集中化・多様化をバランス良く含むようなアルゴリズ ムを構筑寸ることで，より探索が改良できると考えられる。以
下では組合せ最適化問題の特徴であるPOP を利用したこのよ うな改良の実現可能性について検討する。

\section{POP の概念について}

多くの組合せ最適化問題には POP が成立していることをは じめに述べた。POP とは「良い解同士は似通った構造を持っ ている」という漠然とした仮定である。

\section{$2 つ$ 解の共通部分 (類似構造)}

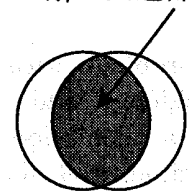

POPの成立あり

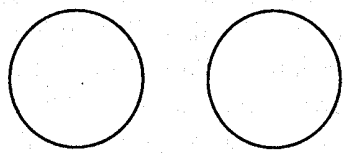

POPの成立なし

Fig. 1: POP の成立と不成立のイメージ

ここでは代表的な組合せ最適化問題である TSP において POP が成立していることを検証する。この検証に際して「良 い解」を定める必要があるが，本論文では局所的最適解を「良 い解」と捉えることとし，局所的最適解同士の解構造の類似性 を調べることで POP の成立を検証する。

\section{1 巡回セールスマン問題（TSP）}

巡回セールスマン（TSP）とは $\mathrm{N}$ 点の都市を全て 1 回ずつ 経由する巡回路の中で巡回路長が最も短いもの（最適巡回路） を求める問題である。一般の TSP の中には都市間の距離が非 対称であるもの（非対称・非 Euclid）や，都市の座標が 3 次 以上の高次元であるものなど様々な設定が可能な比較的柔軟な 形式であるが，本論分では最も基本的な 2 次元の対象 Euclid TSP を用いることとする。

TSP のひとつの解は巡回する都市の順列によって表現され， 隣接する都市同士を組として見ることで都市間を結ぶ枝の集合 を表していると捉えることができる。そして TSP では共有し ている枝の数が多いほど解が類似していると見な寸ことが妥当 であると考えられるため，類似度は「共通している枝の数」で 与えられるものとする。このような類似度は $F: Z^{n} \rightarrow Z^{1}$ の ような形の写像として表現可能であり，類似度を表現する写像 を $F$ とする。

\subsection{POP の検証}

POP の成立は目的関数および近傍定義に依存して決まって くるが,ここでは目的関数として以下を用いた。

$$
\begin{array}{r}
f_{\mathrm{TSP}}(\sigma)=\sum_{k=1}^{n-1} d_{\sigma(k), \sigma(k+1)}+d_{\sigma(n), \sigma(1)} \\
d_{i, j}=\left\{\left|\boldsymbol{x}_{i}-\boldsymbol{x}_{j}\right|\right\rceil
\end{array}
$$

$(\sigma:$ 解をあらわす順列, $n:$ 都市数, $d_{i, j}:$ 都市 $i$ と $j$ の距離) 
この目的関数は TSP LIB 等で用いられている標淮的な形式 の関数である。また，近傍定義は 2-opt 近傍を用いた。2-opt 近傍は図 2 に示されるような近傍で, Euclid TSP のある巡回 路が含む 2 本の枝を取り除き, 別の 2 本の枝を挿入する操作で ある。2-opt 近傍は Lin-Kernighan 近傍や 3 本の枝を入れ替え る 3-opt のような強力な改善能力を持つ近傍と比較すると性能 は劣るが, これらの近傍の基整となっているシンプルな近傍で あり，計算負荷も低いため採用した。

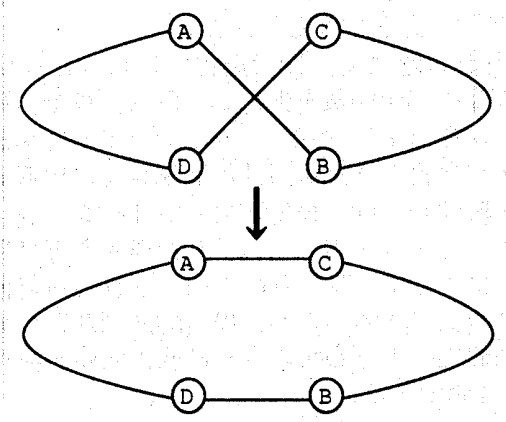

Fig. 2: 2-opt 近傍

これらの設定を用いて TSPLIB の pr107（最適巡回路は図 3）に対してローカルサーチを行い，局所的最適解を 2 点求め, それらの巡回路をプロットした（図 4)。また，ランダムな解 を 2 つ生成し，それらの巡回路をプロットした（図 5)。

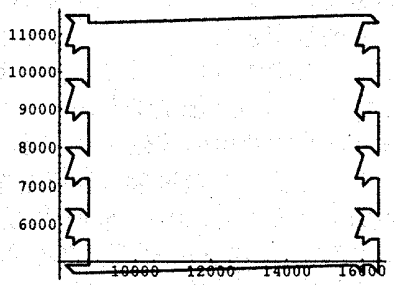

Fig. 3: pr107 の最適巡回路
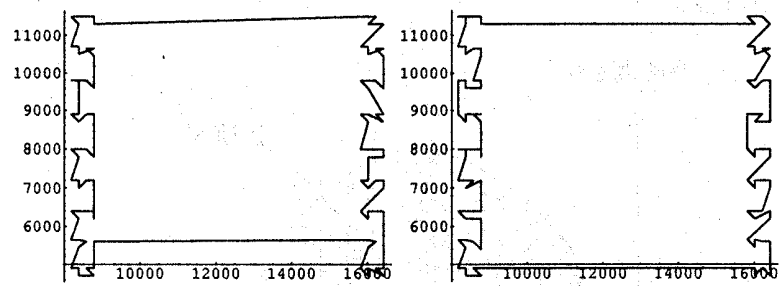

Fig. 4: pr107 の局所的最適解の巡回路

これらの図を比較すると明らかなように，局所的最適解同士 の巡回路に類似性があり,さらに局所的最適解と大域的最適解 の最適巡回路との間にも強い類似性があることが見て取れる。 その一方で, ランダムな解同士にはこれに類するような巡回路 の類似性は全く見られない。

また, 多数の解の間に存在寸る類似度の傾向を定量的に調べ るために，上と同様の設定を用いて，TSPLIB の pr107 問題に 対して初期点をランダムに設定して局所探索を繰り返し，局所 的最適解を 1000 点求めた (この解集合を $S_{\text {localopt }}$ とする)。ま た，これとは別にランダムに 1000 点の解を生成した（この解
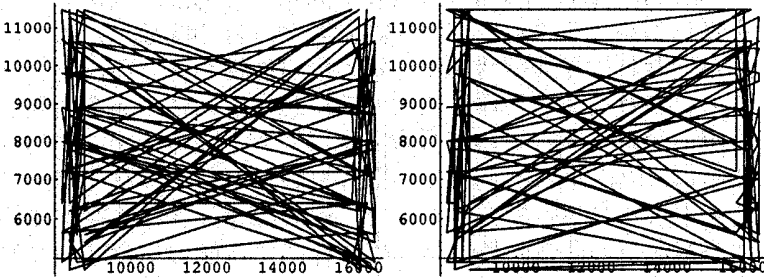

Fig. 5: pr107 のランダムな解の巡回路

集合を $S_{\text {random }}$ とする)。こうして求められた解集合 $S_{\text {localopt }}$, $S_{\text {random }}$ それぞれについて，2つの解 (ペア) を選び出す全て の組合せを取り出し，2つの解が共有している枝の数を調べる ことで類似度を求めた。すなわちある解集合 $S$ の類似度平均 を $\operatorname{Sim}(S)$ とすると,

$$
\begin{aligned}
& \operatorname{Sim}(S)=\frac{1}{|L(S)|} \sum_{d \in L(S)} d \\
& L(S)=\{F(x, y) \mid x, y \in S\}
\end{aligned}
$$

その結果，ランダムな解集合，局所的最適解集合それぞれ の解集合の解の類似度の平均値 $\operatorname{Sim}\left(S_{\text {random }}\right), \operatorname{Sim}\left(S_{\text {localopt }}\right)$ は表 1 のようになった。また，類似度の分布を図 6 に示す。

Table 1: 解の類似度

\begin{tabular}{c|c}
\hline 解集合 & 類似度の平均值 \\
\hline \hline$S_{\text {localopt }}$ & 67.98 \\
\hline$S_{\text {random }}$ & 2.02 \\
\hline
\end{tabular}

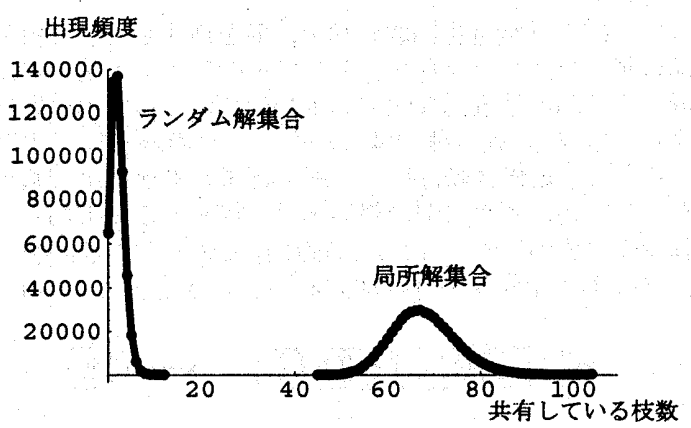

Fig. 6: 相互距離および頻度のプロット

\section{3 考察}

これらの結果から，局所的最適解集合の方がランダム解集合 と比較して平均的に類似度が高い，才なわちランダムな解同士 が共有している枝に対して，局所的最適解同士が共有している 枝が平均的に多いことがわかる。このことはつまり，局所的最 適解同士が (ランダムな解同士のように) 無相関ではなく，何 らかの似通った構造を持つことを示晙している。

また，この検証で用いた組合せ最適化問題であるTSPにお いては，任意の解同士について計算可能である距離に相当する 概念として共通しない枝の数があったが，この距離に相当する 概念が適切であると考えられる理由は，各枝によって独立に決 定する評価値の和が目的関数となっているという構造からであ る。つまり組合せ最適化問題における距離に相当する概念は解 空間依存ではなく目的関数依存であると考えられる。 
例えば 1 機械のジョブショップ問題では解は順列によって表 現されるが, その解に対する評価基準 (目的関数) としては最 大納期遅れや総滞留時間など様々な可能性が考えられる。その ためこの解空間に距離に相当する概念を導入する場合, 同じ解 表現も目的関数によって異なるように解釈されるべきである。 さらに，近傍集合は，現在の探索点から何らかの意味で近いと 言えるような集合であるべきで，適切に尊入された距離に相当 する概念での非負の最低距離内に存在する解の集合は一般的に 有効な近傍集合の候補となる可能性が高い。

次に, ここで示した組合せ最適化問題の特徵をふまえて，ア ルゴリズムの改良の可能性について検討する。

\section{5 アルゴリズムの改良}

\subsection{POP の利用}

組合せ最適化問題の特徵として POP が成立している，すな わち局所的最適解同士が似通った構造を持つ傾向が強いことを TSPについて示した。

このことから，大域的最適解も局所的最適解と多くの枝を 共有していることが容易に推測できる。そしてこの類似性を利 用することにより，良好な解を効率的に探索できる可能性が高 い。これらのことをまとめると，以下のことが言える。

(1) 探索中に求まった局所的最適解の集合の共通部分は, 大 域的最適解との共通部分である可能性が非常に高い

(2) 局所的最適解に含まれる頻度の低い部分は大域的最適解 には含まれる可能性が低い

本論文ではこのうちの後者の可能性に着目し, 大域的最適解 に含まれる可能性の低い部分を積極的に組み替えることによっ て, 多様化のメカニズムを強化する概念を Tabu Search に導 入する。

この際に, 組合せ最適化問題に対寸るメ夕戦略での近傍移動 について，解を構成する部品の組替えであると見なす新しい捉 え方を導入する。

まず, 組合せ最適化問題の解を, 解を構成している何らかの 部品の集合であると見なす。そしてその解の近傍集合が，解を 構成する部品の系統的な除去および付加によって構成されると 捉える（図 7)。近傍移動は近傍内の一つの解を指定すること であるから，近傍移動は現在の解に含まれる部品から適当な部 品を取り除き，新たに別の部品を付け加えることであり，近傍 移動操作 (オペレーション) は解に含まれるどの部品を取り除 き，どのような部品を付け加えるかということに相当する。

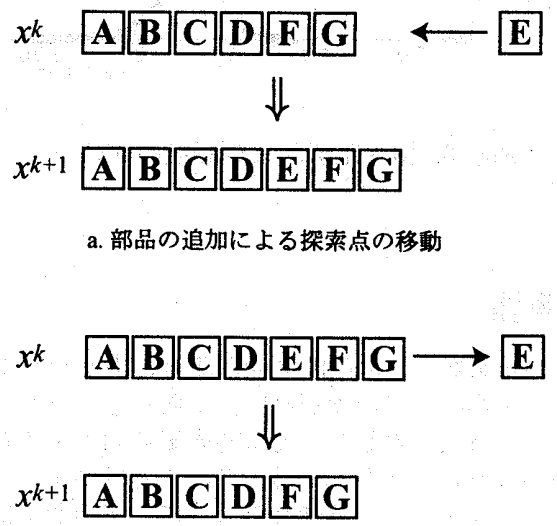

b. 部品の除去による探索点の移動

Fig. 7: 解を構成する部品の挿入および除去

このことをTSP の場合について解釈すると，解を「都市間 を結ぶ枝」という部品の集合として捉えることを意味している。
そして 2-opt 近傍は，解に含まれる枝を 2 つ取り除き，新たに 2 本の枝を付け加えるという作業を系統的に行うことによって 構筑される。ただし， 2-opt 近傍では除去する枝に応じて加え るべき枝が一意に決定するため，オペレーションは「どの 2 本 の枝を取り除くか」ということのみになる。

このような考え方があらゆる組合せ最適化問題の解に適用可 能であるかどうかは必ずしも明らかではないが，問題ごとに強 い特徽を持つ組合せ最適化問題の解構造および近傍定義につい て普遍的な捉え方をすることは，アルゴリズムの沉用性を高め るために有用であると考えられる。

以上の考察を踏まえ, 探索過程で得られた局所的最適解に 含まれる部品の出現回数を保持しておき, 移動の際に用いるオ ペレーションを、「そのオペレーションによって除去される部品 が, それまでに得られた局所的最適解集合に出現した回数」で 評価し，出現回数が低い枝を除去するオペレーションを優先的 に採用することを考える。このような要素を近傍移動の際に考 慮することによって, 良い解の中に含まれる可能性の低い部品 を積極的に除去できることが，局所的最適解と大域的最適解同 士の高い類似性, 寸なわち組合せ最適化問題が持つ特徵である POP から推測できる。

\subsection{Pareto 最適解集合の構成}

集中化・多様化は優れた探索を実現するための鍵となる概念 である。このうちの集中化は近傍内の最良解に常に移動するよ うな Local Searchによって比較的容易に達成されると考えら れる。その一方で, 多様化は集中化の場合のように簡単には達 成できていないため, この 2 つの要素のうち特に多様化をいか にして達成するかが非常に重要な点となる。

これまでに多様化のメカニズムを強化するために，多様化を 考慮するための評価基準としてオペレーションの出現頻度とい う基淮を導入した。この導入によって, 次の移動点を近傍内の 解集合から決定するための評価基準が単一（目的関数值のみの 評価) から複数（目的関数值の評価およびオペレーションの評 価）となった。ここでは，この複数の評価基準をどのように考 虑することが適切であるかについて検討する。

本論文ではこのような複数の評価基準を扱うために, 最適 化の中の多目的最適化という理論に着目し, 許容近傍（移動可 能な近傍) 内について多目的最適化の理論を適用することで Pareto 最適解 (非劣解) 集合を求めることを考える。このよ うに次の移動点を $2 つ$ つ評価基淮についての Pareto 最適解集 合の中から選択することで, 明らかに不適切な解を除外するこ とができる。Pareto 最適解集合の概念は，図 8 のように表現 される。

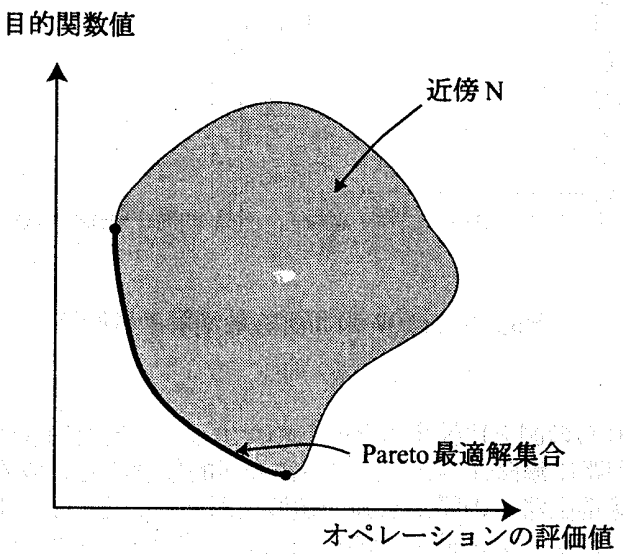

Fig. 8: Pareto 最適解集合

この図からわかるように, Pareto 最適解集合は一般に複数の 解を持つため，次の移動点を決定寸るためにはこれらの解の中 
から何らかの手法を用いて 1 つの解を選び出す必要がある。そ こで, 本論文では制御理論の適応制御にヒントを得て, Pareto 最適解集合の中から選び出す解を，探索の状況に忘じて適応的 に変化させることを考える ${ }^{2}$ 。つまり，最良解が更新された後 のイテレーション数の変化に応して, 採用する解を Pareto 最 適解集合内の目的関数值を重視した解（集中化）から頻度を重 視した解 (多様化) 人と適応的に変化させる。

このために, 探索の初期段階ではまず集中化の評価基準を最 重要視して次の移動点を Pareto 最適解集合の中から選択寸る こととする。これは, 従来の Tabu Search をほぼ同様の振舞 いである。そして，集中化のみに頼った探索による解の改善が 見込めなくなった段階で徐々に多様化の評価基淮を重視するよ うに選択基準をシフトしてゆく。解の改善が見込めなくなった ことは, 最後に最良解が更新されてからのイテレーション数が 一定数以上になったかどうかで判断する。このような適応的な 選択基準の変化により，集中化・多様化の両者の特長を最大限 に生かした探索を実現できることが期待できる。

本論文では，Pareto 最適解集合内からの解の選択基準を定 量的に表現するために，選択基準保数という概念を尊入する。 選択基淮係数とは 0 から 1 の值をとり，選択基淮係数が 1 の時 は集中化の評価基準を最重要視し，0の時は多様化の評価基淮 を最重要視する。また，選択基準係数がその中間の值を取る場 合は, Pareto 最適解集合の要素数を $\left|S_{\text {pareto }}\right|$ ，選択基準係数を $k_{s f}$ とすると, Pareto 最適解集合の中にある $\operatorname{int}\left(k_{s f}\left|S_{\text {pareto }}\right|\right)$ 番目に多様化を重視した解を選択寸る (int $(x)$ は $\mathrm{x}$ を超えない 最大の整数を与える関数とする)。本論文では選択基淮係数を 以下の式のようなイテレーション数の周期関数とした。

$$
g(x)=\left\{\begin{array}{cl}
1 & , 0 \leq x<\frac{1}{2} T \\
2-\frac{x}{T / 2} & , \frac{1}{2} T \leq x<T
\end{array}\right.
$$

この関数は図 $9(T=200)$ のような形状をしている周期関 数であり，イテレーション数の増加に応じて集中化から多様化 に段階的に解の選択基淮がシフトすることが期待できる。関数 が周期関数となっているのは，多様化を重視することによって 解を組替えた後に，再び集中化を重視して解を改善することを 狙いとしているためである。

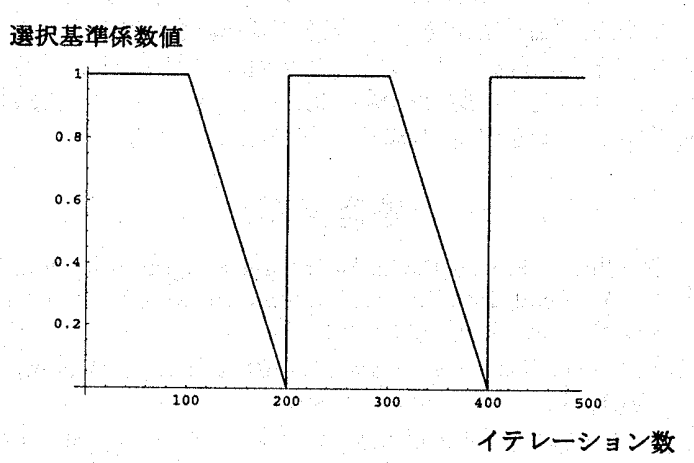

Fig. 9: 選択基準係数の関数形状

\section{3 多軌道化}

これまでの説明によってPOPを考慮した多様化のメカニズ 厶は実現可能であるが，実際にはこのままの改良を加えただけ のアルゴリズムを適用したとしても十分な探索性能の向上は期 待できない。その理由は, 本論文での多様化のメカニズムが局

2このように探索状況に応じてアルゴリズムのパラメータ（あるい はパラメータに相当する要素) を適応的に変化させるアルゴリズムと しては, Reactive Tabu Search[7] などが挙げられる。
所的最適解の情報をフィードバックするという仕組みとなって いるために, 探索性能がその時点で得られている局所的最適解 の質および量に大きな影響を受けるためである。また，GA や PSO (Particle Swarm Optimization) に見られるように, 多 点探索が多くの問題に有効であると言われている。そのため本 論文でもフィードバックする情報の質・量の両者の向上および 探索の効率化を狙いとして探索軌道を多軌道化することを考え る。具体的には, 挆索軌道数を $r$ とすると, $r$ 点の初期点をラ ンダムに生成し，それぞれの挆索点について独立に近傍移動を 繰り返しを行う。そして, 各軌道間の相互作用として, 局所的 最適解の情報を全ての軌道で共有する。このような多軌道化に よって, 単軌道の場合と比較して, 探索の初期の段階であって も軌道数の分だけ数多くの局所的最適解が得られていることが 期待できる。

\section{6 提案手法のアルゴリズム}

前章まででアルゴリズムの改良の戦略について詳しく説明し てきた。これまで検討してきた改良を導入した本論文の提案手 法は, 以下の通りである。

【Tabu Search with multi-criteria のアルゴリズム】

Step1：初期点群を生成する。それぞれの軌道の Tabu List を 初期化する。

Step2: それぞれの軌道について, Tabu Listに含まれない移 動可能な近傍内探索を目的関数值, 除去される部品が局 所的最適解に含まれていた頻度の 2 つの評価基準を用い た多目的最適化問題として捉えて, Pareto 最適解集合を 構成する。

Step3: Pareto 最適解集合の特定の解を選択し, その解を次 の移動点とする。どの解を選択するかは最良解が更新さ れてからのイテレーション数に応じて式 (6) のように適 応的に変化させる。

Step4: Step3 での移動に用いた操作を Tabu Listに追加する。

Step5: Step2〜Step4 までを規定の回数繰り返し，探索中に 求まった最良解を出力して終了。

このようなアルゴリズムを構成することにより, Tabu Search の持つ強力なローカル探索という特長を保ったまま, POP を 考慮した多様化のメカニズムが実現され, 探索の効率化が達成 されることが期待できる。次章では提案手法をベンチマーク問 題に適用することによって，手法の性能を検証する。

\section{7 数値実験による検証}

提案手法の挙動を検証するためにベンチマーク問題として TSP を用いて数值実験を行った。

\section{1 多様化の検証}

初めに多様化の効果を定性的および定量的に調べるため, TSP にTabu Search と提案手法を適用し，探索中に調べた枝（部 品）の種類の分布を求めた。図 10 は従来の Tabu Search およ び提案手法において調べられた枝の分布を示す。

図 10 について説明を付け加えると，横軸・縦軸がいずれも TSP の都市を表しており，都市 A と都市 B を結ぶ枝が探索中 に 1 度でも調べられた場合は黒, 1 度も調べられなかった場合 は白としてプロットしたものである。なお,ここで取り扱っ ている問題は対称な TSP なので都市 A と都市 B を結ぶ枝・都 市 $\mathrm{B}$ と都市 $\mathrm{A}$ を結ぶ枝は同等であり，それらをまとめて扱っ ているので図は下三角のみ値を持つ。

この図から, Tabu Search と比較して提案手法では探索中 に調べている枝の種類が多い，すなわち多様化が実現できて いることが定性的に見て取れる。具体的な数字を举げると， 
Tabu Search が調べた枝の種類は 1788 (枝の種類の総数は ${ }_{136} \mathrm{C}_{2}=9180$ である），提案手法が調べた枝の種類は 2965 で ある。

次に，実際の探索において性能が改善されたかを検証するた めに, いくつかのベンチマーク問題に対して Tabu Search, 提 案手法の各アルゴリズムを適用する。
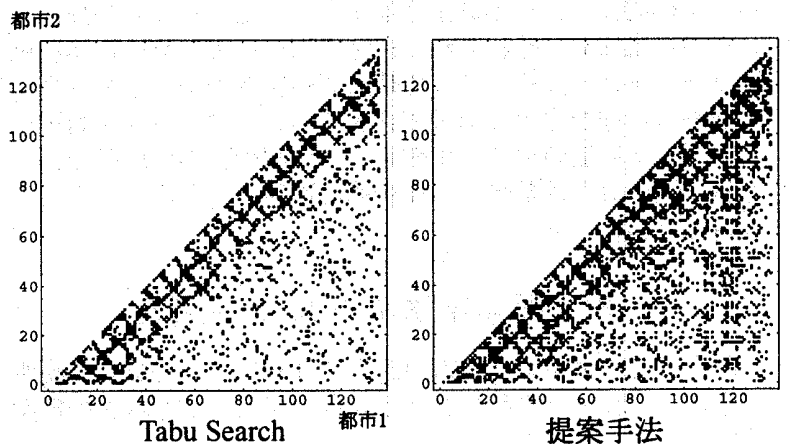

提案手法

Fig. 10: 探索中に調べた枝の種類の分布

\section{2 探索性能の比較}

提案手法の性能を検証するために，単純な Tabu Search と 本論文の提案手法を TSP に適用する。問題は TSPLIB の中 から 2 次元ユークリッド TSP である pr107, pr124, pr136, pr144, pr152, pr226, pr439を用いた。それぞれの問題につ いて，2-opt 近傍を用い，表 2 のようなパラメータを設定した。 これらのパラメータのうち,ループ数は計算負荷の制約から概 放 $O(N)$ 程度とした。また Tabu List の長さは事前の数値解 析によって求めた適切な值を採用している。

以上のような設定で，ランダムな解を初期点として提案手 法及びTabu Search を 1 つの問題につき 100 回適用し，得ら れた解の平均評価値を求めた。計算量を同程度に調整するため に, Tabu Search については対応する提案手法の軌道数の回数 だけアルゴリズムを適用し，その中で求まった最良值を採用し た。結果は表 3 のとおりである。ここで表中のパーセンテージ は最適巡回路長に対する相対誤差を表している。

Table 2: パラメータの設定

\begin{tabular}{c|c|c|c}
\hline & TabuList の長さ & ループ数 & 軌道数 \\
\hline \hline $\operatorname{pr} 107$ & 200 & 1000 & 6 \\
$\operatorname{pr} 124$ & 200 & 1000 & 6 \\
$\operatorname{pr} 136$ & 300 & 2000 & 6 \\
$\operatorname{pr} 144$ & 300 & 2000 & 6 \\
$\operatorname{pr} 152$ & 300 & 2000 & 8 \\
$\operatorname{pr} 224$ & 500 & 2000 & 8 \\
$\operatorname{pr} 439$ & 700 & 4000 & 8 \\
\hline
\end{tabular}

表 3 の結果からわかるように, Tabu Searchによる探索が 今回適用した問題に対してある程度良い結果を残しており，提 案手法による改善量自体は大きくないが，今回対象とした問題 の多くについて提案手法がより良い結果を残している。しかし ながら，この数值実験に見られた探索結果の改善が実際に多様 化の導入によって達成されたかどうかについてはより精密な数 值実験によって検証する必要がある。
Table 3: 計算結果

\begin{tabular}{c|c|c|c}
\hline & TabuSearch & 提案手法 & 最適巡回路長 \\
\hline \hline pr107 & $44394.72(0.21 \%)$ & $44432.96(0.29 \%)$ & 44303 \\
pr124 & $59058.9(0.049 \%)$ & $59060.9(0.050 \%)$ & 59030 \\
pr136 & $97506(0.79 \%)$ & $96958(0.19 \%)$ & 96772 \\
pr144 & $58597.73(0.10 \%)$ & $58548(0.019 \%)$ & 58537 \\
pr152 & $74043.81(0.49 \%)$ & $73769.44(0.12 \%)$ & 73682 \\
pr224 & $81138.23(0.96 \%)$ & $80784.96(0.51 \%)$ & 80369 \\
pr439 & $109467.26(2.10 \%)$ & $108399.10(1.10 \%)$ & 107217 \\
\hline
\end{tabular}

\section{8 おわりに}

本論文を要約すると，以下のとおりである。

(1) メ夕解法 (発見的近似解法) はPOP の成立を前提とした 手法であり，集中化・多様化が優れたアルゴリズムの鍵と なると考えられる。Tabu Search は強力な集中化のメカ ニズムを持つが，多様化のメカニズムについてはより改 善できる可能性がある

(2) 組合せ最適化問題において成立している POP を考虑す ると, 探索過程で求まった局所的最適解の情報を探索に フィードバックすることで解が含んでいる比較的悪い部 品を積極的に組み替えることができ，多様化のメカニズ ムが強化されると予想できる

(3) 集中化と多様化のメカニズムをバランス良く含むような 方法として適応的な概念を導入し，集中化による探索に よる改善の可能性が低くなった時点で多様化のメカニズ ムの優先度を上げることでバランスの取れた探索の実現 が予想できる

(4) 以上の検郡を踏まえたアルゴリズムを提案し，典型的な組 合せ最適化問題である TSP を用いて従来の Tabu Search と比較した多様化の検証および探索性能の検証を行った

また，今後の提案手法の課題としては，より探索に有効な履 歴情報のフィードバック方法の開発が考えられる。さらにメタ 解法全般にかかわる課題として, 集中化・多様化の各メカニズ 厶の定量的評価方法の検討，組合せ最適化問題のクラス分け, そして TSP 以外の一般の組合せ最適化問題に対しても POP を成立させるための離散凸構造 $[8,6,10,9]$ に立脚した解構造・ 近傍定義の一般的手法の構築などが挙げられる。

\section{参考文献}

[1] F. Glover: Future Paths for Integer Programming and Links to Artificial Intelligence, Computers and Operations Research, Vol.13, pp.533-549 (1986)

[2] F. Glover:Tabu Search Part I, ORSA Journal of Computing, Vol.1, No.3, pp.190-206 (1989)

[3] 久保, 宮本: 「メ夕解法の新しいフレームワーク」, 電気学会論文 誌 C 分冊, Vol.121-C, No. 6 (2001)

[4] 柳浦, 茨木 :「組合せ最適化一メ夕戦略を中心として一」朝倉書 店 (2001)

[5] 久保 :「巡回セールスマン問題への招待 I 〜III」,オペレーション ズリサーチ, Vol.39, pp.25-31, pp.91-96, pp.156-162 (1994)

[6] 室田, 藤田他 : 「倣散構造とアルゴリズム I VII」，近代科学社 $(1992 \sim 2000)$

[7] R. Battiti, G. Tecchilli: [The Reactive Tabu Search」, ORSA Journal on Computing Vol. 6, No. 2, pp. 126-140 (1994)

[8] 室田：離散凸解析]，共立出版 (2001)

[9] 今野, 山下: 「非線形計画法」, 日科技連 (1978)

[10] 杉原, 浅野, 茨木, 山下 :「アルゴリズム工学一計算困難問題へ の挑戦一」, 共立出版 $(2001)$

[11] 久保：「組合せ最適化とアルゴリズム」，共立出版（2000） 